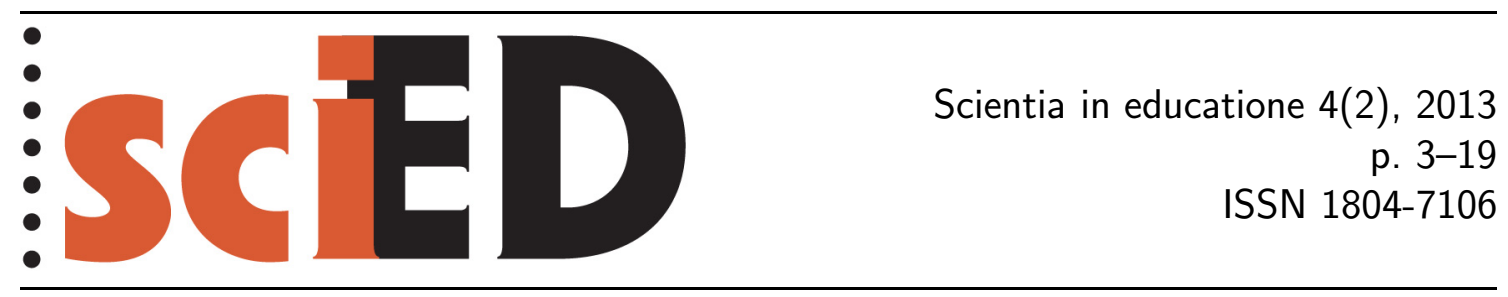

\title{
Miskoncepcie pojmov organickej chémie u absolventov základných škôl po školskej reforme na Slovensku
}

\author{
Monika Míkva, Lubomír Held
}

\begin{abstract}
Abstrakt
Početné výskumy dokazujú, že žiaci majú mylné predstavy v mnohých oblastiach chémie a problémy s pochopením viacerých chemických pojmov. Mylné koncepcie žiakov sú pevne zakotvené $\mathrm{v}$ ich kognitívnych štruktúrach, sú trváce, sú často odolné voči rôznorodým zmenám a nie je lahké ich odstránit. Náš článok demonštruje žiacke miskoncepcie v oblasti organickej chémie. Článok prezentuje kvalitatívny výskum žiackych predstáv a vedomostí v oblasti organickej chémie realizovaný na slovenských školách. Uvádza mnohé žiacke miskoncepcie a zistenia v tejto časti chémie. Predkladá tiež niekolko odporúčaní pre elimináciu žiackych mylných predstáv v oblasti prírodných vied a pre zefektívnenie procesu ich vyučovania, ktoré by mohli zvýšit záujem žiakov o štúdium prírodných vied a byt neocenitelným „motorom“ ich vnútornej motivácie.
\end{abstract}

Klíčová slova: organická chémia, miskoncepcie, kvalitatívny výskum, prírodné vedy.

\section{Misconceptions of Organic Chemistry Concepts Held by Elementary Students after Slovak School Reform}

\begin{abstract}
Many research reports have proved that pupils hold misconceptions in majority of chemistry fields and have also problems to understand many of chemical concepts. Misconceptions are strongly anchored in students' cognitive structures, they are durable, resistant to change and not easy to be eradicated. Our contribution demonstrates students' misconceptions in the field of organic chemistry. It presents qualitative research of students' misconceptions and knowledge in the field of organic chemistry conducted at Slovak schools. It specifies many of students' misconceptions and findings in this area of chemistry. It also puts forward several recommendations for elimination of students' misconceptions in the field of science, for making the teaching-learning process more effective and closer to students, to increase their interest toward study of science and their intrinsic motivation.
\end{abstract}

Key words: organic chemistry, misconceptions, qualitative research, natural sciences. 


\section{1 ÚvOD}

V posledných desatročiach bolo vykonaných mnoho výskumov so zámerom zistit, aké sú predstavy žiakov v chémii. Reprezentatívny prehlad o rôznych žiackych prekonceptoch a miskonceptoch publikovali i Doulík a Škoda (2010). Žiacke prekoncepty a mylné predstavy boli zistované vo viacerých oblastiach chémie - vo fyzikálnej chémii, anorganickej chémii, všeobecnej chémii, elektrochémii, termodynamike, menej v organickej chémii. Do tejto oblasti smeruje aj náš príspevok. O priebežných zisteniach z našich výskumov sme referovali na konferencii v Smoleniciach (Míkva, 2012).

Organická chémia sa všeobecne považuje za náročnú oblast chemického vzdelávania. V protiklade so stredoeurópskou tradíciou sa jej vyučovanie väčšinou sústreduje na vyššom sekundárnom stupni, kde sa predpokladá vyššia intelektová a vedomostná úroveň študentov, ktorá je daná vyšším vekom, dľžkou vzdelávania, ale aj selekciou populácie so zámerom d’alšieho štúdia. Napriek tomu napríklad Rushton et al. (2008) v oblasti organickej chémie zistili, že stredoškoláci majú v tejto oblasti chémie mylné predstavy o základných pojmoch a princípoch. Zistili, že niektoré mylné koncepcie v chémii u študentov neustále pretrvávajú, a to od začiatku vyučovania chémie.

Topal, Oral a Özden (2007) sa zaoberali pojmom aromatickost' a aromatickými zlúčeninami v organickej chémii. Výsledky ich štúdie ukázali, že študenti majú mylné predstavy o aromatických zlúčeninách. Zistili, že pojem aromatickost je v niektorých učebniciach chémie nedostatočne, neúplne alebo nesprávne vysvetlený, a poznatky založené na tomto základnom pojme spôsobujú neskôr d’alšie miskoncepcie.

Schmidt (1996) zistil, že stredoškoláci majú mylné predstavy o medzimolekulových silách medzi organickými molekulami a nedokážu predvídat relatívne body varu jednoduchých organických zlúčenín. Rozvinul testové otázky, ktoré umožňujú učitelom získat informácie o naivných predstavách svojich žiakov v tejto oblasti.

Dori a Kaberman (2012) v rámci svojej štúdie vyvinuli špeciálny počítačový program, prostredníctvom ktorého sa žiaci učili tvorit molekulové a štruktúrne vzorce organických zlúčenín, rôzne modely organických zlúčenín, kde prechádzali z makroskopickej úrovne do mikroskopickej, neprístupnej priamemu vnímaniu. Autori dokazujú, že program pomáha žiakom lepšie pochopit molekulárne štruktúry a väzby v organických zlúčeninách.

Szu, Nandagopal et al. (2011) skúmali faktory, ktoré ovplyvňujú výkonnost' a výsledky žiakov v organickej chémii. Výsledky ich výskumu naznačujú, že je velmi dôležité aktívne zapájat žiakov do riešenia problémov a najrôznejších praktických úloh v tomto vednom odbore.

Salah a Dumon (2011) vo svojej štúdii zistili, že študenti majú mylné predstavy o hybridizácii orbitálov, atómových orbitáloch a molekulových orbitáloch. Podla nich medzery v osvojení týchto pojmov môžu predstavovat prekážku pre zmysluplné pochopenie reaktivity organických zlúčenín.

Simpson (1988) odhalil, že stredoškoláci majú mylné predstavy o nukleofilných substitúciách v organickej chémii. Vo svojej štúdii sa zaoberá i tým, ako túto tému efektívne vyučovat.

O dôležitosti základných chemických princípov v organickej chémii hovoria Cartrette a Mayo (2011). Vo svojom výskume opisujú mylné predstavy študentov o teórii kyselín a zásad v kontexte organickej chémie.

Sadek, Brown a Wan (2011) navrhli laboratórny experiment pre výučbu základných laboratórnych techník, v rámci ktorého sa žiaci oboznámia s niektorými základnými organickými látkami a ich vlastnostami. 
Smith a Jacobs (2003) poukazujú na to, že v učebniciach organickej chémie je mnoho vedeckých omylov. Vo svojej štúdii skúmali, ako študenti používajú učebnice organickej chémie, hodnotili ich študijné návyky i samotné učebnice.

Bryan (2007) vo svojom výskume, zameranom na predstavy študentov v organickej chémii zistil, že niektoré z mylných predstáv študentov boli spôsobené nesprávnym pochopením výkladu obsahu nájdeného v ich zošitoch, zatial' čo ostatných sa dopúštali učitelia zovšeobecňovaním a zjednodušovaním výkladu. Identifikácia týchto mylných predstáv môže umožnit̉ učitelom, aby sa s nimi oboznámili, ale aj premýšlali o vlastných vyučovacích metódach a stratégiách.

Okrem nesprávnej (nevedeckej) žiackej interpretácie sveta (prírodných javov a zákonitostí) a jeho fungovaní, ktorú môžu žiaci nadobudnút prostredníctvom svojich zážitkov a skúseností, môžu tiež žiacke mylné predstavy vzniknút i na základe už spomínaného učitelovho nedostatočného, zjednodušeného vysvetlenia určitej problematiky, ale i z postupu chemického vzdelávania, ako i zo zaužívaných modelov vzdelávania, nevedeckého používania bežných slov, zamieňania modelov a obrazov s realitou, vysvetlovaní chemických javov pomocou submikroskopickej úrovne i d’alších faktorov, ako sú metódy vzdelávania, obsah vzdelávania či učebnice chémie.

Väčšina zahraničných výskumov študuje žiacke mylné predstavy skôr z oblasti všeobecnej chémie či anorganickej chémie. Predstavy a poznatky žiakov z organickej chémie sú vo výskumoch diskutované v menšej miere, čo naznačuje aj vyššie uvedený prehlad. Môže to byt dôsledkom toho, že organická chémia sa väčšinou v zahraničí (anglosaských krajinách) začína vyučovat až na stredných školách, a to v odbornejšom kontexte. Zahraničné výskumy zamerané na organickú chémiu sú preto skôr orientované na študentov stredných a vysokých škôl, a riešia čast̉ chémie zaoberajúcu sa organickými zlúčeninami, ich získavaním, štúdiom ich štruktúry, priebehom ich reakcii odbornejšie, vedeckejšie a menej popisne.

$\mathrm{Na}$ Slovensku, podobne ako v iných stredoeurópskych krajinách, sa organická chémia vyučuje už v počiatočnom chemickom vzdelávaní, teda na úrovni ISCED 2. V súčasnosti sa organická chémia začína vyučovat v 9. ročníku na základnej škole. Náročnost’ obsahu organickej chémie je zrejme jeden z dôvodov, ktorý spôsobil jej zaradenie až na konci štvorročného chemického vzdelávacieho cyklu. Je súčastou vzdelávacej oblasti Clovek a príroda v Státnom vzdelávacom programe Slovenskej republiky. V 9. ročníku na základných školách a v 4. ročníku gymnázia s osemročným štúdiom sa používa nová učebnica chémie od Vicenovej a Ganajovej (2012).

V rámci organickej chémie sa žiaci na slovenských základných školách oboznamujú s jednoduchými organickými látkami a ich charakteristikou, s väzbovostou uhlíka a jeho schopnostou tvorit rôzne uhlíkové retazce, s rozličnými uhlovodíkmi a ich základnými reakciami, s derivátmi uhlovodíkov, s prírodnými zdrojmi uhlovodíkov, s rôznymi prírodnými či umelými organickými látkami, ktoré ovplyvňujú život človeka.

Aj napriek školskej reforme, ktorá začala fungovat vo vzdelávacej sústave v Slovenskej republike od 1. 9. 2008, je výučba chémie na ZŠ viac teoretická ako praktická. V slovenských školách i nad’alej prevláda deduktívny spôsob výučby chémie (prírodovedných predmetov). Kroky, ktoré boli doteraz v rámci reformy uskutočnené, mali len minimálny dopad na obsah, formy či metódy vzdelávania. Samostatná práca žiakov (realizovaná na základe predpísaných laboratórnych prác) má vo vyučovacom procese prevažne len úlohu verifikačnú, čiže overuje sa všeobecné tvrdenia, zistujú sa vedomosti žiakov, alebo má iba doplnkový charakter. Na vyučovacích hodinách chémie absentujú: zvýšená aktivita žiakov, experimentovanie, vyjadrenie vlastných názorov či intenzívne diskusie. 
Efektívne vyučovanie si však vyžaduje posun roly učitela z roly externej autority a jediného zdroja informácií na niekoho, kto sprístupňuje zmysel vedeckých myšlienok a zdôvodňuje ich potrebu. Toto si samozrejme tiež vyžaduje posun v role učiaceho sa z pasívneho prijímatela informácií na aktívneho konštruktéra svojich vlastných poznatkov. Pri osvojovaní nových vedomostí preto treba klást́ dôraz na samostatnú prácu žiakov, vlastné bádanie a objavovanie (konštruktivistický prístup), nielen na pasívne prijímanie hotových poznatkov.

Hoci niekol'ko štúdií ukázalo, že bádatel’ská činnosṫ žiakov pozitívne ovplyvňuje záujem žiakov a motiváciu žiakov pre štúdium prírodných vied (napr. Rosenthal, 1987; Bean, 1996; Kovac, 1999). Je zvyčajne velmi tažké vytvorit zaujímavú vyučovaciu hodinu s objavnými (induktívnymi) vzdelávacími postupmi poznávania prostredníctvom formálneho vzdelávania. Dôvody, ktoré túto skutočnost' stažujú, môžu byt: nedostatok času učitela, materiálne, technické a metodické nedostatky školy, finančné nedostatky školy, slabá podpora vedenia školy a aj niektoré predsudky učitel'ov i žiakov (strach, úzkost', nechut, odpor atd').

Mnohé výskumy (napr. Zoller, 1990; Shibley et al., 2010) potvrdzujú, že súčasný stav vedomostí a predstáv žiakov v problematike organickej chémie, ale i v oblasti prírodných vied je nelichotivý. Stále je nedostatok informácií o žiackom vnímaní v tejto časti chémie zaoberajúcej sa organickými zlúčeninami, preto je potrebné vykonávat aj d’alšie výskumy, ktoré by boli zamerané na predstavy a vedomosti žiakov v tejto oblasti, ale i v ostatných prírodných vedách všeobecne.

Naším príspevkom chceme prispiet k odborným štúdiám venujúcim sa žiackemu vnímaniu v oblasti organickej chémie, pričom sa zameriavame na predstavy a vedomosti žiakov slovenských základných škôl o pojmoch a javoch v tejto oblasti chémie.

\section{CiEL, METÓdY A VÝSKUMNÁ VZORKA}

Náš príspevok vychádza zo širšieho výskumu, ktorého ciel’om bolo skvalitnenie vzdelávania v organickej chémii, s využitím konštruktivistických prístupov. Pri výskumoch tohto typu sa spravidla mapuje aktuálny stav predstáv žiakov. V našom prípade je táto úloha o to dôležitejšia, že od roku 2008 sa v slovenských školách realizuje obsahová reforma kurikula. Pracovná hypotéza vychádza z celkovej situácie sprevádzajúcej reformu, a to je:

- koncepčná neujasnenost a nepripravenost kurikulárnych zmien,

- nezvyklá rozdrobenosṫ chemického vzdelávania do štyroch ročníkov pri nízkej hodinovej dotácii,

- zaradenie organickej chémie do posledného ročníka, ktorý je tradične sústredený na prechod žiakov na stredné školy, pričom sa hlavný dôraz venuje iným vyučovacím predmetom.

V dôsledku tejto nepriaznivej situácie a pretrvávajúcej praxe transmisívneho vzdelávania očakávame nízku úroveň zvládnutia obsahu organickej chémie žiakmi s početnými miskoncepciami. Charakter a smerovanie týchto miskoncepcií chceme popísat v našom príspevku. Hlavným cielom nášho výskumu je odpovedat’ na otázku: aké miskoncepcie súvisiace s organickou chémiou budú sprevádzat absolventov základných škôl pri štúdiu na stredných školách?

Ako hlavnú výskumnú metódu zistovania konceptov žiakov sme použili fenomenografické interview. Ako doplnkovú metódu zberu dát sme zvolili test s otvorenými 
širokými otázkami. Test obsahoval 25 položiek s otvorenými otázkami (otvorené otázky s krátkou odpoved’ou a otvorené otázky so širokou odpoved’ou). Otázky v teste mali obdobné znenie, ako otázky v skupinovom fenomenografickom interview. Žiaci tak mali znova vysvetlit a objasnit svoje odpovede, čo prispelo $\mathrm{k}$ triangulácii údajov. Otázky sú koncipované velmi široko a všeobecne, aby nenavádzali žiakov na „školské“ odpovede.

Niektoré otázky z testu z výskumu žiackych predstáv a vedomostí o pojmoch a javoch v organickej chémii na slovenských školách:

1. Ako vyzerá uhlík? Objasni.

2. Kde všade sa uhlík nachádza? Objasni.

3. Prečo uhlík môže tvorit až 14 miliónov zlúčenín? Prečo je to možné? Objasni.

4. Uved’ názov zlúčeniny na obrázku. Čo znamená kruh v jej vzorci? Objasni.

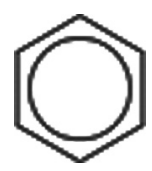

5. Kolko atómov vodíka je v molekule metánu? Vysvetli, ako si dospel k tomuto číslu.

6. Kolko atómov uhlíka je v molekule metánu? Vysvetli, ako si dospel k tomuto číslu.

7. Kolko elektrónov má uhlík na poslednej valenčnej vrstve? Vysvetli, ako si dospel k tomuto číslu.

8. Čo je aromatická zlúčenina? Vysvetli.

9. Ktoré zlúčeniny môžeme považovat za aromatické? Uved' príklady.

10. Kolko väzbový je uhlík v organických zlúčeninách? Vysvetli, ako si dospel $\mathrm{k}$ tomuto číslu.

11. Čo je fotosyntéza?

12. Čo je potrebné k tomu, aby nastala fotosyntéza?

Celkový čas na vyplnenie testu vrátane pokynov k vyplňovaniu bol 45 minút. Nahrávky interview boli prepísané a konfrontované s výsledkami testov. Dáta z testov slúžili ako komplementárne údaje k vyhodnoteniu interview. Pre zámery tohto príspevku považujeme za postačujúce kvalitatívne spracovanie výsledkov a ich „volné prerozprávanie" napriek tomu, že na našom pracovisku máme bohaté skúsenosti aj s velmi sofistikovaným spracovaním kvalitatívnych výskumov (Orolínová, 2007). Validitu výskumu sme zabezpečili priamym kontaktom s účastníkmi výskumu a citovaním otázok a replík pri analýze transkriptu. Trianguláciu sme zabezpečili opätovným pýtaním sa na jav inak koncipovanými otázkami, a tiež použitím doplnkovej metódy zberu dát - testu s otvorenými otázkami.

Kedže sa organická chémia vyučuje v 9. ročníku základných škôl počas prvého i druhého polroka a deviataci majú tiež množstvo aktivít a povinností, v rámci ktorých sa pripravujú na stredné školy, realizácia výskumu v deviatych ročníkoch 
základných škôl by bola časovo aj organizačne náročná a navyše bez časového odstupu od bezprostredných vzdelávacích aktivít z organickej chémie. Preto sme naše zistovanie sústredili do „nasledujúceho školského roka.“ Dostupnú výskumnú vzorku tvorili žiaci „nasledujúcich“, teda prvých ročníkov stredných škôl v trnavskom kraji. Bolo vykonaných 8 fenomenografických skupinových interview, každého skupinového interview sa zúčastnilo 8 žiakov, celkom sa zúčastnilo 64 žiakov, z toho 31 dievčat a 33 chlapcov. Priemerný vek respondentov bol 15,7 rokov. Skupinové interview bolo pološtruktúrované a trvalo asi 40 minút.

Výskum bol realizovaný na začiatku školského roka na štyroch gymnáziách a štyroch stredných odborných školách v trnavskom kraji, čo približne zodpovedá zloženiu základného súboru žiakov základných škôl. Nepredpokladáme vplyv strednej školy na predstavy a vedomosti žiakov napriek tomu, v záujme dôveryhodnosti uvádzame zoznam zúčastnených škôl:

1. Gymnázium Angely Merici, Trnava

2. Gymnázium Pierra de Coubertina, Pieštany

3. Gymnázium Ivana Kupca, Hlohovec

4. Gymnázium Jána Baltazára Magina, Vrbové

5. Stredná odborná škola, odbor kozmetička - vizážistka, Vrbové

6. Stredná odborná škola, odbor floristika, Rakovice

7. Stredná odborná škola, odbor kuchár - čašník, Pieštany

8. Stredná odborná škola, odbor technika a prevádzka dopravy, Trnava

\section{VÝSLEDKY VÝSKUMU}

Analýza získaných dát potvrdzujú, že absolventi základných škôl nenapíňajú dostatočne projektované vzdelávacie ciele z oblasti organickej chémie. „Chemické“ predstavy žiakov sú załažené mnohými miskoncepciami. Nižšie v texte uvádzame dominantné žiacke miskoncepcie a zistenia, ktoré vyplynuli z analýzy empirického materiálu.

Organické látky žiaci opisovali hlavne pomocou atribútov a charakteristík zmyslového vnímania, na základe svojich predchádzajúcich skúseností, len velmi ojedinele žiaci opisovali látky prostredníctvom ich zloženia a existujúcich vzţahov medzi atómami v molekulách a väzieb medzi nimi. I pri vzájomnej komparácii dvoch jednoduchých látok, cukru a soli, žiaci opisovali rozdiely medzi nimi výhradne senzoricky (perceptuálne), bez uvedomenia si časticového zloženia látok a existencie mikrosveta:

„.. cukor je sladký, sol' je slaná... “

„.. kryštály soli sú menšie ako kryštály cukru. . ."

„... sol' je belšia ako cukor... “

„... sol’ je jemnejšia ako cukor... “

„.. . cukor je zdravší ako sol'. . . 
- Pri otázke Ako vyzerá uhlík? zostali viacerí žiaci zaskočení. Niektorí z nich si vôbec nevedeli uhlík predstavit a iní si tento nekovový prvok predstavovali ako „niečo“ čierne, červené či žeravé, ako plyn či uhlie.

- Niektorí žiaci mali problém s určením väzbovosti atómov v molekulách organických zlúčenín. V niektorých prípadoch väzbovost uhlíka a d’alších prvkov v organických zlúčeninách iba intuitívne odhadovali.

„.. uhlík je 6-väzbový..."

„.. uhlík je 3-väzbový..."

„.. . uhlík môže mat’ nekonečne vela väzieb. . “

- Väčšina žiakov „vníma“, že v organických zlúčeninách majú uhlíkové atómy schopnost tvorit väzby s inými atómami a tiež medzi sebou, že väzby medzi atómami uhlíka môžu byṫ jednoduché i násobné, a tiež že existujú i cyklické uhlovodíky, ale ich zdôvodnenia a predstavy boli v tomto smere značne naivné a skreslené. Pri zdôvodňovaní a znázorňovaní väzieb uhlíka s inými prvkami mnohí žiaci zabúdali na počet väzieb, ktoré môžu atómy vytvorit a jednotlivé chemické prvky medzi sebou nezmyselne spájali, čo len potvrdzovalo, že s aplikáciou školou prezentovaných poznatkov majú značné problémy.

„...v uhlovodíkoch nemôže byt štvoritá väzba, lebo uhlík by už nemohol nič prijímat..."

„... záleží to od elektronegativity daných prvkov, jaké tam budú väzby, či jednoduchá alebo tie dvojité..."

„.. cyklické uhlovodíky sú také, ktoré sa opakujú. . “"

„.. . uhlík sa môže viazat s viacerými uhlíkmi, lebo uhlík je viacúčelový... "

„...pri viazaní uhlíkov môžu vzniknút viaceré tvary, napríklad tvar oxidu uhličitého..."

- Predstavy žiakov o priestorovom usporiadaní organických látok sú značne skreslené. Väčšina z nich nemala žiadne alebo len mylné predstavy o priestorovom rozložení väzieb v molekulách uhlovodíkov. Priestorový tvar molekúl organických zlúčenín a priestorové rozloženie väzieb v molekulách organických zlúčenín si niektorí žiaci predstavovali prostredníctvom ich štruktúrnych vzorcov a prezentácie ich predstáv boli prevažne dvojrozmerné.

- V chémii sú základnými informačnými jednotkami symboly, vzorce a názvy prvkov a zlúčenín. Niektorí žiaci mali problémy s „čítaním“ značiek chemických prvkov i vzorcov organických zlúčenín, nevedeli, čo niektoré chemické symboly a vzorce znamenajú a tiež ako ich majú interpretovat'.

„.. $\mathrm{O}_{2}$ sú dve molekuly kyslíka, O je kyslík a dvojka je počet molekúl..."

„.. $\mathrm{O}_{2}$ je voda..."

„... uhlík má značku U..."

„.. $\mathrm{C}_{2} \mathrm{H}_{2}$ je acetón..."

„.. $\mathrm{CH}_{2}=\mathrm{CH}_{2}$ je bután. . .

- Väčšina žiakov s velkými tažkostłami objasňovala pojem štruktúrny vzorec. Viaceré vyjadrenia žiakov ukázali, že nemajú ujasnené základné chemické 
pojmy a mnohé chemické pojmy sa učia naspamät, bez hlbšieho pochopenia súvislostí. Mnohí žiaci nevedeli, čo daný pojem znamená, a aj ked' niektorí odpovedali správne, štruktúrne vzorce organických zlúčenín nevedeli znázornit, alebo ich zaznačili chybne.

„... štruktúrny vzorec znázorňuje štruktúru väzieb v atóme... “

„... štruktúrny vzorec určuje počet väzieb v prvku. . “"

„... štruktúrny vzorec je rozložený vzorec prvkov a molekúl. .."

„... štruktúrny vzorec vyjadruje postavenie látok v molekule... “

„... štruktúrny vzorec znázorňuje počet prvkov v prvku... “

- Žiaci v mnohých svojich vyjadreniach nerozlišovali medzi základnými chemickými pojmami ako atóm, molekula či zlúčenina. V spomínaných základných chemických pojmoch mali žiaci značný zmätok. Väčšina žiakov nevedela, aký chemický dej je chemická reakcia, za chemickú reakciu považovali spôsoby oddelovania zložiek zmesí, či fyzikálno-chemický proces rozpúštanie.

„... uhlík je zlúčenina..."

„.. $\mathrm{O}_{2}$ je molekula vody..."

„... síra je žltá zlúčenina... “

„.. destilácia je chemická reakcia, kde sa oddelí alkohol od pôvodnej zmesi. . .

„... pri chemických reakciách sa mení tvar, skupenstvo, chut, farba a podobne..."

„... sladenie kávy je chemická reakcia, lebo pridaním cukru vzniká sladká káva... "

„... ked’ sladíme kávu prebieha chemická reakcia, lebo čiastočky cukru sa rozkladajú v horúcej vode..."

- Mnohí žiaci poznali základné, najjednoduchšie a niektoré známe organické zlúčeniny, ale len niektorí vedeli uvieste aj ich vlastnosti či využitie. Skoro polovica žiakov nepoznala vlastnosti základných organických zlúčenín, alebo si ich zamieňala, či mylne vysvetlovala.

„.. etanol je plyn..."

„... etanol je rozpustný vo vode, pretože má menšiu schopnost’ pútat’ si elektróny chemickej väzby..."

„.. . benzén je zelený plyn a dobré rozpúštadlo. . . "

„.. . benzén sa používa v domácnosti na dezinfekciu rán. . ."

„.. . metán je štiplavý plyn. . .

„.. etán je kvapalina v benzíne. . “

„.. a acetón je smrtel’ne jedovatý plyn... “

„.. benzín sa skladá z ropy..."

„.. benzín má v sebe cukor..."

„.. benzín obsahuje oxid uhličitý... “

„.. . uhlie je živočíšny produkt. . “ 
- Pojem nasýtená zlúčenina nechápu žiaci ako zlúčeninu obsahujúcu iba jednoduché väzby medzi atómami uhlíka a pojem nenasýtená zlúčenina ako zlúčeninu obsahujúcu násobné väzby (dvojité, trojité) medzi atómami uhlíka, ale si ich spájajú a objasňujú ich prostredníctvom definície pre nasýtený a nenasýtený roztok, ktorá je však tiež mylná, nekompletná a nesúvislá.

„... nasýtená zlúčenina už viac nemôže prijat’ iné látky, nenasýtená zlúčenina môže prijímat' iné látky... "

„... nasýtené zlúčeniny už nepohlcujú látky, nenasýtené stále pohlcujú látky..."

„... nasýtené zlúčeniny sú také, ktoré nemôžu prijat̉ viac tukov... “

„... nasýtené zlúčeniny už nemôžu prijímat d’alšie sypké látky, lebo už sú nasýtené, to je ked’ rozpúštame cukor..."

- Žiaci chápu nesprávne pojem aromatická zlúčenina, pojem si vôbec nespájajú so štruktúrou zlúčeniny a konjugovanými dvojitými väzbami. Odlišujú aromatické zlúčeniny od ostatných zlúčenín iba podl’a vône, alebo naopak podla zápachu.

„.. a aromatická zlúčenina nemusí len voňat, ale aj smrdiet... “

„.. a aromatická zlúčenina vylučuje vonnú látku zo seba... “

„... aromatickú zlúčeninu môžeme cítit... "

„.. aromatická zlúčenina je benzín. .."

Žiaci tiež neregistrovali rozdiel medzi molekulou cyklohexánu a benzénu, či benzén zarad’ovali do skupiny cykloalkánov. Väčšina žiakov nevedela vysvetlit, čo znamená kruh v štruktúrnom vzorci benzénu. Aj ked’ niektorí žiaci pomenovali kruh v štruktúrnom vzorci najjednoduchšieho arénu ako benzénové jadro, ale bližšie tento termín nevedeli špecifikovat a objasnit. Iní žiaci si mysleli, že kruh v štruktúrnom vzorci benzénu predstavuje určitý uzavretý cyklus či dôkaz 6-prvkovej zlúčeniny alebo že je v ňom ukryté benzénové jadro či si kruh predstavovali ako nejaký obal tejto aromatickej zlúčeniny.

- Žiaci mali tiež problém uvieste príklady nebezpečných, zdraviu škodlivých organických zlúčenín. V mnohých výpovediach si organické zlúčeniny zamieňali za zlúčeniny anorganické $\left(\mathrm{CO}, \mathrm{CO}_{2}, \mathrm{HCN}, \mathrm{KCN}, \mathrm{HCl}\right)$, či za bakteriálne ochorenie (anthrax) alebo mali o účinkoch niektorých organických zlúčenín mylné predstavy. Niektorí žiaci si tiež zamieňali uhlovodíky s derivátmi uhlovodíkov.

- Žiaci mali značný zmätok a mnohé miskoncepcie i v enviromentálnych otázkach. Niektorí si zamieňali ozónovú dieru so skleníkovým efektom či nepoznali zlúčeniny, ktoré tieto javy podporujú. Žiaci si boli vedomí rozsahu enviromentálnych problémov, ale len nejasne si ich spájali s konkrétnymi dôvodmi a s konkrétnymi dôsledkami. Ozónovú dieru si žiaci predstavujú skutočne ako dieru v atmosfére a nie ako oblast stratosféry s oslabenou vrstvou ozónu.

- Väčšina žiakov sa domnievala, že freóny sú nebezpečné a škodlivé vo vyšších vrstvách zemskej atmosféry, pretože v týchto vrstvách môžu reagovat s ozónom. Kedže sa ozón, podla nich, v najnižšej vrstve zemskej atmosféry nenachádza, freóny s ním nemôžu reagovat, a preto nie sú v troposfére nebezpečné. Žiaci si vôbec neuvedomovali, že so stúpajúcou nadmorskou výškou sa v jednotlivých vrstvách atmosféry mení teplota, atmosférický tlak a tiež chemické 
zloženie zemskej atmosféry, čo môže rôzne ovplyvnit vlastnosti mnohých chemických zlúčenín či ich reakcie $\mathrm{v}$ jednotlivých častiach atmosféry.

- O procese fotosyntézy mali žiaci množstvo alternatívnych predstáv, ktoré boli v rozpore s vedeckými predstavami. Žiaci si mysleli, že fotosyntéza poskytuje rastlinám energiu, vela žiakov si myslelo, že svetlo je pre rastlinu dôležitá živina, a že je to reakčné činidlo fotosyntézy, bez ktorého by fotosyntéza nemohla prebiehat. Väčšina žiakov si myslela, že rastliny získajú energiu potrebnú na všetky ich životné procesy priamo zo Slnka alebo z prostredia - z pôdy, vody, či dokonca z oxidu uhličitého.

\section{DiskUsia A POROVNANIE SO ZAHRANIČNÝMI VÝSKUMAMI}

Výsledky nami realizovaného výskumu potvrdili, že žiaci-absolventi základných škôl majú z organickej chémie množstvo mylných predstáv: o aromatickosti, o väzbách a molekulových štruktúrach v organickej chémii, o fotosyntéze, ale i o vlastnostiach organických zlúčenín. Zdá sa, že tu popísané miskoncepcie sú len vrcholom ladovca, ktorého podstatná časte nám zostáva skrytá. Pokúsime sa preto o možných príčinách tohto stavu pouvažovat aj využitím informácií zo zahraničných výskumov.

Viaceré výpovede žiakov ukazujú, že žiaci nemajú jasno v základných chemických pojmoch - atóm, molekula, chemický prvok, chemická zlúčenina, chemická látka, chemická reakcia, chemické zloženie, chemická štruktúra a tiež nechápu mnohé d’alšie chemické pojmy a javy. Driverová (1989) zdôrazňuje, že tieto pojmy sú klúčové v chémii i submikroskopickom svete a ich zmysluplné pochopenie je velmi dôležité pre d’alšie vzdelávanie $\mathrm{v}$ chémii. Ich nedostatočné chápanie podporuje u žiakov mylné predstavy v rôznych oblastiach chémie. Podobné zistenie uvádzajú aj d’alšie štúdie (McDermott, 1984; Shibley et al., 2010; Cartrette, Mayo, 2011 a i.), ktoré potvrdzujú, že jedným z hlavných dôvodov miskoncepcií v chémii, je nedostatočné a nesprávne pochopenie predchádzajúcich poznatkov.

Analýza získaných dát a mnohé výpovede žiakov ukázali, že žiaci sa mechanicky učia mnohé organické pojmy, ale hlbší zmysel a súvislosti v získaných poznatkoch nemajú. Aj ked' žiaci vedeli vymenovat niektoré vlastnosti organických zlúčenín či chemické pojmy a javy z organickej chémie alebo z chémie všeobecne, mnohokrát nevedeli vyslovené pojmy vysvetlit, či si spojit dané pojmy s inými pojmami a témami, a uviest’ medzi nimi súvislosti či logické prepojenia. Žiaci tiež často nevedeli mnohé chemické pojmy a teórie správne aplikovat̉ v praktických otázkach či prepojit teoretické poznatky s informáciami z praxe.

Možnou príčinou uvedeného stavu môže byt, podla Holeca a kol. (2010), v školách stále prevládajúci deduktívny spôsob výučby, i napriek realizácii školskej reformy v roku 2008, ale i zotrvačnost, nielen učitelov chémie, pri dodržiavaní transmisívnych prístupov k vyučovaniu či používanie učebníc a učebných materiálov, kde prevládajú informácie teoretického charakteru bez dôrazu na praktické uplatnenie zákonov prírody v bežnom živote a praxi. Aj napriek školskej reforme, ktorá začala fungovat vo vzdelávacej sústave v Slovenskej republike od 1. 9. 2008 na všetkých stupňoch a typoch škôl, učebnice chémie obsahujú prevažne úlohy na mechanické opakovanie fráz používaných v učebnici alebo na vyhladávanie d’alších informácií. Učebnice neobsahujú bádatel’ské aktivity či problémové úlohy, prostredníctvom ktorých by si žiaci rozvíjali vyššie kognitívne procesy a overovali správnost’ pochopenia chemických pojmov a javov či využívali svoje vedomosti v rôznych praktických úlohách. 
Bean (1996) a Kovac (1999) zdôrazňujú, že pre organickú chémiu, ale i iné prírodné vedy, je dôležité používanie interaktívnych metód, ktoré podporujú rozvoj logického a kritického myslenia, rozvoj osobnosti či schopnost riešit problémy a tiež zvyšujú záujem o chemické (prírodovedné) vzdelávanie. Lynch a Trujillo (2011) v tomto smere vyzdvihujú dôležitost́ efektívnych vyučovacích stratégií pre zmysluplné osvojenie si daného učiva, ale i motiváciu učitelov chémie vo vyučovacom procese. Podla Rosenthala (1987) je z hladiska motivácie žiakov i pre d’alšie štúdium prírodných vied dôležité experimentovanie - žiaci musia experiment „zažit“, čo značne napomáha k zmysluplnejšiemu pochopeniu obsahu chémie i iných prírodných vied.

V súčasnosti sa, podla Holeca a kol. (2010), na slovenských školách, vo všetkých prírodovedných predmetoch, len vo velmi malej miere využívajú experimentálne činnosti rôzneho typu. Ak majú žiaci skúsenosti s uskutočňovaním experimentov, vo väčšine prípadov ide najmä o demonštračné experimenty, ktoré realizuje sám učitel. Žiacke experimenty sú na slovenských školách skôr výnimkou.

Organické zlúčeniny a ich vlastnosti žiaci zväčša opisovali perceptuálne, na základe svojich predchádzajúcich laických skúseností, alebo len intuitívne, bez racionálneho premýšlania a tiež bez uvedomenia si časticového zloženia látok a existujúcich vzţahov medzi atómami v organických zlúčeninách a väzieb medzi nimi. Žiaci „videli“ len minimálne súvislosti medzi zložením a priestorovým usporiadaním molekúl organických zlúčenín a ich vlastnostami.

Z mnohých žiackych výpovedí bolo zjavné, že žiaci vnímajú svet, kde prebiehajú rôzne udalosti a procesy, v makroskopickom rozsahu, neuvedomujú si existenciu mikrosveta, dejov a skrytých mechanizmov či chemických procesov, ktoré prebiehajú medzi časticami v mikrosvete. Žiaci sa riadia a fungujú v makroskopickom svete hmoty a je pre nich tažké robit presuny medzi makroskopickým a mikroskopickým pohladom na hmotu. Tieto zistenia sú v súlade i s d’alšími medzinárodnými štúdiami, ktoré dokazujú, že „abstraktno“, ktoré nie je prístupné priamemu zmyslovému poznávaniu, si nevedia žiaci predstavit’ a majú problém „presunút“ svoje uvažovanie z makrosveta do oblasti mikrosveta (Ben-Zvi et al., 1986; Mohan et al., 2009; Kruse, Roehrig, 2005; Tan, Taber, 2009).

Mnohí žiaci mali mylné predstavy o väzbovosti atómov v organických molekulách i o spôsobe viazania atómov v organických zlúčeninách. Taktiež mali skreslené predstavy o priestorovom usporiadaní atómov a väzieb v organických zlúčeninách či silovom pôsobení medzi atómami a väzbami v štruktúre organických zlúčenín. Väčšina žiakov vôbec nevnímala molekuly organických zlúčenín priestorovo a neuvedomovala si pri ich štruktúre tretí rozmer.

Mnohé štúdie na zlepšenie tejto problematiky (Dori, Kaberman, 2012; Lou et al., 2012; Box, 2011) odporúčajú používat na vyučovacích hodinách organickej chémie konkrétne modely molekúl organických zlúčenín a špeciálne počítačové programy, počítačové animácie či audiovizuálne pomôcky, zamerané na modelovanie organických molekúl. Tieto pomôcky a programy, podla spomínaných štúdií, u žiakov zlepšujú chápanie molekulárnej podstaty hmoty, molekulárnych štruktúr organických zlúčenín a vztahov vo vnútri ich molekúl, pochopenie niektorých pojmov z organickej chémie či reakčných mechanizmov organických zlúčenín a tiež rozvíjajú priestorovú predstavivost. Podla Stullu et al. (2012) konkrétne modely organických zlúčenín či špeciálne počítačové programy, zamerané na modelovanie organických molekúl a práca s nimi, podporujú schopnost vizualizácie a nahradzujú zložité žiacke mentálne procesy, čo vplýva na hlbšie pochopenie štruktúry organických molekúl. Pursell (2009) v tomto smere navrhuje namiesto počítačov, ktoré nie 
sú v niektorých školách dostupné, využívat tiež papierové kartičky alebo mobilné telefóny.

V prírodovedných predmetoch, teda i v organickej chémii, je vysoká miera abstrakcie a zovšeobecňovania. Mnoho javov a pojmov z organickej chémie nie je prístupných priamemu zmyslovému poznávaniu. Mnohé organické pojmy boli pre žiakov velmi abstraktné, žiaci mnohé organické pojmy nevedeli vysvetlit či použit pri objasňovaní určitých javov z organickej chémie.

Reddish (1994), Christian a Talanquer (2012) uvádzajú, že vzhladom k abstraktnej povahe organickej chémie je dôležité, aby žiaci využivali, podla Piagetovho modelu kognitívneho vývinu, myslenie dané pre štádium formálnych operácií. Bunce a Hutchinson (1993) v tomto kontexte zistili, že žiaci, ktorí využívajú formálne myslenie majú väčší úspech v organickej chémii, i v chémii všeobecne, a hlbšie rozumejú chemickým pojmom a javom ako žiaci, ktorí uvažujú len v štádiu konkrétnych operácií. Zoller (1993) odporúča pri vyučovaní prírodovedných predmetov používat interaktívne vzdelávacie metódy, ktoré, podla neho, rozvíjajú vyššie úrovne myslenia ako tradičné vzdelávacie metódy, ktoré kladú dôraz na nižšie kognitívne spôsobilosti.

Žiaci používali na objasnenie organických pojmov a javov mnohé pojmy, zákonitosti a vysvetlenia zo všeobecnej či anorganickej chémie (chemická väzba, nasýtený roztok, hustota, emulzia, rozpúštadlo, elektronegativita a i.), pričom mnohým pojmom a zákonitostiam $\mathrm{z}$ daných vedných odborov nedostatočne rozumeli a nemali medzi nimi hlbšie súvislosti. Pri vysvetlovaní mnohých organických pojmov a javov bola u žiakov zjavná konceptuálna zmätenost', nesúvislé a nevedecké vyjadrovanie a celková dezorientácia v chemických poznatkoch a ich vzájomných vztahoch.

Francisco et al. (1998) odporúča v tomto smere využívat na hodinách chémie skupinové diskusie, ktoré, podla neho, zlepšujú slovné vyjadrenia a celkové komunikatívne schopnosti a tiež porozumenie danému učivu a chemickým pojmom. Lopez et al. (2011) navrhuje používat́ vo vyučovaní organickej chémie pojmové mapy nielen na diagnostiku žiackych miskoncepcií, ale i na štrukturáciu a opakovanie učiva, čo vedie $\mathrm{k}$ zmysluplnejšiemu pochopeniu organických pojmov a ich vzájomných vzṫahov.

Barber a Mourshed (2007) tvrdia, že v problematike žiackych mylných predstáv v chémii je nutná produkcia vysoko skúsených učitelov s úplným pochopením obsahu základných chemických pojmov, aby sa vytvoril kvalitný vzdelávací systém, ktorý slúži potrebám žiakov. Kvalitní učitelia majú významný vplyv na úspech vzdelávacích systémov (Barber, Mourshed, 2007) a tiež na akademickú úspešnoste žiakov (Sanders, Rivers, 1996).

S cielom riešit problém žiackych miskoncepcií v chémii, musia byt', podla Sheehanovej et al. (2011), učitelia pripravení využívat výsledky výskumov o chemických miskoncepciách v praxi a snažit sa, prostredníctvom nich, miskoncepcie eliminovat a odstraňovat. Učitelia musia taktiež dôkladne rozumiet základným pojmom v chémii a mat relatívne málo mylných predstáv.

Stúdia Sheehan, Childs (2011) naznačuje, že vzdelávacie systémy v mnohých krajinách nepodporujú znižovanie mylných predstáv v chémii a konceptuálnu zmenu v kognitívnych štruktúrach žiakov. Vzdelávacie systémy tak produkujú žiakov s vysokým počtom mylných predstáv v chémii a s nízkym pochopením pojmov. Sheehanová a Childs (2011) tiež zistili, že je možné u žiakov zvýšit úroveň kognitívnych schopností a znížit počet mylných predstáv v chémii pomocou starostlivo navrhnutých vzdelávacích stratégií a vzdelávacích programov.

V rámci diskusie sumarizujeme spomínané odporúčania a pridávame i d’alšie zlepšenia, ktoré navrhli viacerí výskumníci pre elimináciu žiackych mylných predstáv 
v oblasti prírodných vied a pre zefektívnenie procesu ich vyučovania, v niektorých bodoch adresnejšie v oblasti organickej chémie:

- používat interaktívne metódy a experimentovanie, ktoré podporuje rozvoj logického a kritického myslenia, rozvoj osobnosti či schopnost riešit problémy a tiež zvyšujú záujem o chemické (prírodovedné) vzdelávanie (Bean, 1996; Rosenthal, 1987),

- zabezpečit, pri aplikácí inovatívnych prístupov a metód vo vzdelávaní prírodovedných predmetov, rozvíjaní klúčových kompetencií a vedeckých zručností u žiakov - materiálne, technické a metodické zabezpečenie škôl (Lim et al., 2011),

- oboznamovat žiakov zmysluplne so značnými súvislostami so základnými chemickými (prírodovednými) pojmami a javmi, aby sa zamedzilo zbytočným žiackym alternatívnym predstavám v oblasti prírodných vied (Shibley et al., 2010),

- používat na vyučovacích hodinách organickej chémie konkrétne modely molekúl organických zlúčenín a špeciálne počítačové programy, počítačové animácie či audiovizuálne pomôcky, zamerané na modelovanie organických molekúl (Dori, Kaberma, 2012),

- vzhladom k abstraktnej povahe organickej chémie využívat a u žiakov rozvíjat, podla Piagetovho modelu kognitívneho vývinu, myslenie dané pre štádium formálnych operácií (Christian, Talanquer, 2012),

- využívat na hodinách chémie skupinové diskusie, ktoré zlepšujú slovné vyjadrenia a celkové komunikatívne schopnosti a tiež porozumenie danému učivu a chemickým pojmom (Francisco et al., 1998),

- organizovat dlhodobé kurzy pre budúcich i praktizujúcich učitelov prírodovedných predmetov pre aplikáciu inovatívnych vzdelávacích stratégií a medzipredmetových vztahov a väzieb vo vyučovaní prírodovedných predmetov (Loverude et al., 2011),

- produkovat vysoko skúsených učitelov s úplným pochopením obsahu základných chemických pojmov, aby sa vytvoril kvalitný vzdelávací systém, ktorý slúži potrebám žiakov (Barber, Mourshed, 2007),

- využívat výsledky výskumov o žiackych miskoncepciách v oblasti prírodných vied v praxi a snažit sa, prostredníctvom nich, žiacke miskoncepcie eliminovat a odstraňovat (Sheehan et al., 2011),

- oboznamovat́ deti už v predškolskom veku s vedeckým (t.j. primerane objektívnym) poznávaním sveta, v ktorom žijú a to ekvivalentne ich úrovni myslenia. Učit deti premýšlat nad realitou tak, aby si postupne osvojovali indukčný postup poznávania, ktorý prispieva k rozvíjaniu prírodovednej gramotnosti, logického myslenia či zručností vedeckej práce a komunikácie (Žoldošová, 2006).

\section{ZÁVER}

V uskutočnenom výskume predstáv a vedomostí absolventov základných škôl o pojmoch a javoch v organickej chémii sme identifikovali určité zistenia, ktoré stručne rekapitulujeme do krátkej a prehladnej podoby: 
- absolventi základných škôl, ktorí sa podielali na výskume, majú množstvo mylných predstáv z organickej chémie: o aromatickosti, o väzbách a molekulových štruktúrach v organickej chémii, o fotosyntéze i o vlastnostiach organických zlúčenín,

- organická chémia je považovaná žiakmi za náročný vyučovací predmet - obsahuje vela abstraktných pojmov, má velký rozsah a náročný obsah jednotlivých kapitol,

- žiaci sa učia mnohé organické pojmy naspamät bez hlbšieho pochopenia a súvislostí,

- žiaci nemajú jasno v základných chemických pojmoch - atóm, molekula, chemický prvok, chemická zlúčenina, chemická látka, chemická reakcia, chemické zloženie, chemická štruktúra,

- žiaci nevedia pojmy a javy v organickej chémii, ale i v chémii všeobecne prepojit $\mathrm{s}$ informáciami z praxe,

- žiakom robí problémy vyjadrovat sa súvisle a zmysluplne,

- žiaci „fungujú“ v makroskopickom svete hmoty a je pre nich tažké robit presuny medzi makroskopickým a mikroskopickým pohladom na hmotu,

- žiaci nevnímajú molekuly organických zlúčenín priestorovo a neuvedomujú si pri ich štruktúre tretí rozmer,

- žiaci majú zmätok vo viacerých organických pojmoch a pomocou nich nevedia vysvetlit mnohé chemické javy.

V diskusii sme v súvislosti s u nás identifikovanými problémami vo vzdelávaní v oblasti organickej chémie ponúkli prehlad rôznych zväčša zahraničných odporúčaní a zlepšení vyučovania prírodných vied (v niektorých prípadoch adresnejšie organickej chémie), ktoré môžu žiakom pomôct’ zmysluplnejšie pochopit mnohé prírodovedné pojmy a javy a uviest’ medzi nimi súvislosti, či prepojit teoretické poznatky s informáciami z praxe.

Dúfame, že zistené údaje, charakterizujúce stav vyučovania organickej chémie v podmienkach slovenského školského systému, pomôžu nám, d’alším výskumníkom i pedagogickej verejnosti vnímat’ a následne riešit problémy chemického vzdelávania.

\section{LITERATURA}

BARBER, M., MOURSHED, M. How the world's best-performing school systems come out on top. New York: McKinsey \& Co., 2007, 56 p.

Dostupné na: 〈http://mckinseyonsociety.com/downloads/reports/

Education/Worlds_School_Systems_Final.pdf $\rangle$

BEAN, J. C. Engaging ideas: The Professor's guide to integrating writing, critical thinking and active learning in the classroom. Seattle: Jossey-Bass, Seattle University, 1996, $320 \mathrm{p}$.

BEN-ZVI, R., EYLON, B., SILBERSTEIN, J. Is an atom of copper malleable? Journal of chemical education, 1986, vol. 63, no. 1, p. 64-66. 
BOX, V. G. S. Using molecular modeling to understand some of the more subtle aspects of aromaticity and antiaromaticity. Journal of Chemical Education, 2011, vol. 88 , no. 7 , p. 898-906.

BRYAN, L. CH. H. Identifying Students' Misconceptions in 'A-Level' Organic Chemistry. Innova Junior College, 2007.

Dostupné na: 〈http://conference.nie.edu.sg/2007/paper/papers/SCI352.pdf〉

BUNCE, D. M., HUTCHINSON, K. D. The use of the GALT (Group Assessment of Logical Thinking) as a predictor of academic success in college chemistry. Journal of Chemical Education, 1993, vol. 70, p. 183-187.

CARTRETTE, D. P., MAYO, P. M. Students' understandings of acids/bases in organic chemistry contexts. Chemistry Education Research and Practice, 2011, vol. 12, p. 29-39.

DORI, Y. J., KABERMAN, Z. Assessing high school chemistry students' modeling sub-skills in a computerized molecular modeling learning environment. Instructional Science. 2012, vol. 40, p. 69-91.

DRIVER, R. Students' conceptions and the learning of science. International Journal of Science Education, 1989, vol. 11, p. 481-490.

FRANCISCO, J. S., NICOLL, G., TRAUTMANN, M. Integrating multiple teaching methods into a general chemistry classroom. Journal Chemical Education, 1998, vol. 75 , p. 210-213.

HOLEC, S., KMEŤOVÁ, J., SPODNIAKOVÁ PFEFFEROVÁ, M., RAGANOVÁ, J., HRUŠKA, M. Testovanie prírodovednej gramotnosti PISA 2006. Fakulta prírodných vied, Univerzita Mateja Bela, Banská Bystrica, 2010, s. 59-69.

CHRISTIAN, K., TALANQUER, V. Modes of reasoning in self-initiated study groups in chemistry. Chemistry Education Research and Practice, 2012, vol. 13, no. 3, p. 286-295.

KOVAC, J. Student Active learning methods in General Chemistry. Journal of Chemical Education, 1999, vol. 76, p. 120.

KRUSE, R. A., ROEHRIG, G. H. A Comparison Study: Assessing Teachers' Conceptions with the Chemistry Concepts Inventory. Journal of chemical education, 2005, vol. 82, no. 8, p. 1246-1250.

LIM, Ch., TAY, L., HEDBERG, J. Employing an Activity-Theoretical Perspective to Localize an Educational Innovation in an Elementary School. Journal of Educational Computing Research, 2011, vol. 44, no. 3, p. 319-344.

LOPEZ, E., NANDAGOPAL, K., CARDIN, N., SHAVELSON, R. J., PENN, J. H. Validating the use of concept-mapping as a diagnostic assessment tool in organic chemistry: implications for teaching. Chemistry Education Research and Practice, 2011, vol. 12 , no. 2 , p. 133-141.

LOU, S., LIN, H., SHIH, R., TSENG, K. Improving the effectiveness of organic chemistry experiments through multimedia teaching materials for junior high school students. Turkish Online Journal of Educational Technology - TOJET, 2012, vol. 11, no. 2, p. 135-141. 
LOVERUDE, M. E., GONZALEZ, B. L., NANES, R. Inquiry-Based Course in Physics and Chemistry for Preservice K-8 Teachers. Physical Review Special Topics: Physics Education Research, 2011, vol. 7, no. 1.

LYNCH, D. J., TRUJILLO, H. Motivational Beliefs and Learning Strategies in Organic Chemistry. International Journal of Science and Mathematics Education, 2011, vol. 9 , no. 6 , p. 1351-1365.

McDERMOTT, L. Research on Conceptual Understanding in Mechanics. Physics Today, 1984, vol. 37, p. 4-32.

MĹKVA, M. Miskoncepcie žiakov v organickej chémii. InAktuálne trendy vo vyučovaní prírodných vied. Zborník z medzinárodnej konferencie Smolenice 15.-17. október 2012. Trnava : Trnavská univerzita v Trnave, Pedagogická fakulta, 2012, s. 66-72.

MOHAN, L., CHEN, J., ANDERSON, Ch. W. Developing a multi-year learning progression for carbon cycling in socio-ecological systems. Journal of Research in Science Teaching, 2009, vol. 46, no. 6, p. 675-698.

OROLÍNOVÁ, M. Skúsenosti z uplatnenia zakotvenej teórie pri skúmaní detských a laických interpretácií javov. Acta Fac. Paed. Univ. Tyrnaviensis, Ser. D, 2004, č. 8 , s. $75-85$.

ROSENTHAL, L. C. Writing across the curriculum: Chemistry lab reports. Journal of Chemical Education, 1987, vol. 64, p. 996-998.

PURSELL, D. P. Adapting to student learning styles: engaging students with cell phone technology in organic chemistry instruction. Journal of Chemical Education, 2099, vol. 86, no. 10, p. 1219-1222.

REDISH, E. F. The implications of cognitive studies for teaching physics. American Journal of Physics, 1994, vol. 62, no. 6, p. 796-803.

RUShtON, G. T., HARDY, R. C., GWALtNey, K. P., LEWIS, S. E. Alternative conceptions of organic chemistry topics among fourth year chemistry students. Chemistry Education Research and Practice, 2008, vol. 9, no. 2, p. 122-130.

SADEK, C. M., BROWN, B. A., WAN, H. A cost-effective two-part experiment for teaching introductory organic chemistry techniques. Journal of Chemical Education, 2011, vol. 88, no. 10, p. 1431-1433.

SALAH, H., DUMON, A. Conceptual integration of hybridization by algerian students intending to teach physical sciences. Chemistry Education Research and Practice, 2011, vol. 12 , no. 4, p. 443-453.

SANDERS, W. L., RIVERS, J. C. Research Project Report: Cumulative and Residual Effects of Teachers on Future Student Academic Achievement. Knoxville : University of Tennessee Value-Added Research and Assessment Center.

SHEEHAN, M., CHILDS, P. E. ITS chemistry! An intervention programme aimed at developing thinking skills in chemistry. Paper presented at European Science Education Research Association (ESERA) conference, Lyon, France, Strand 2, available online at: $\langle$ http://lsg.ucy.ac.cy/esera/e_book/base/ebook/strand2/ebook-esera 2011_SHEEHAN_02.pdf $\rangle$, accessed 21/6/12.

SHEEHAN, M., CHILDS, P. E., HAYES, S. The chemical misconceptions of preservice science teachers at the University of Limerick: Do they change? IOSTENWE : Contemporary Issues in Science and Technology Education, 2011. 
SHIBLEY, I. A., AMARAL, K. E., AURENTZ, D., MCCAULLY, R. J. Oxidation and Reduction Reactions in Organic Chemistry. Journal of Chemical Education, 2010, vol. 87, no. 12, p. 1351-1354.

SCHMIDT, H. J. Students' Understanding of Molecular Structure and Properties of Organic Compounds. St. Louis : MO, 1996.

SIMPSON, P. Organic reaction mechanisms in the sixth form part 1. School Science Review, 1988, vol. 70, no. 251, p. 77-82.

STULL, A. T., HEGARTY, M., DIXON, B., STIEFF, M. Representational translation with concrete models in organic chemistry. Cognition and Instruction, 2012, vol. 30, no. 4, p. 404-434.

SZU, E., NANDAGOPAL, K., SHAVELSON, R. J., LOPEZ, E. J., PENN, J. H., SCHARBERG, M., HILL, G. W. Understanding academic performance in organic chemistry. Journal of Chemical Education, 2011, vol. 88, no. 9, p. 1238-1242.

ŠKODA, J., DOULÍK, P. Prekoncepce a miskoncepce v odborových didaktikách. Ústí nad Labem : Univerzita J. E. Purkyně, 2010, 273 s.

TAN, K. D., TABER, K. Ionization energy: implications of preservice teachers' conceptions. Journal of chemical education, 2009, vol. 86, no. 5, p. 623-629.

TOPAL, G., ORAL, B., ÖZDEN, M. University and secondary school students' misconceptions about the concept of "Aromaticity" in organic chemistry. International Journal of Environmental and Science Education, 2007, vol. 2, no. 4, p. 135-143.

VICENOVÁ, H., GANAJOVÁ, M. Chémia pre 9. ročník základnej školy a 4. ročník gymnázia s osemročným štúdiom. Bratislava : EXPOL PEDAGOGIKA, 2012, $142 \mathrm{~s}$.

ZOLLER, U. Students' misunderstandings and misconceptions in college freshman chemistry (General and Organic). Journal of Research in Science Teaching, 1990, vol. 27, no. 10, p. 1053-1065.

ZOLLER, U. Are lecture and learning compatible - maybe for LOCS - unlikely for HOCS. Journal of Chemical Education, 1993, vol. 70, no. 3, p. 195-197.

ŽOLDOŠOVÁ, K. Východiská primárneho prírodovedného vzdelávania. Bratislava : VEDA - TYPI Universitas Tyrnaviensis, 2006, 167 s.

\section{POĎAKOVANIE}

Príspevok vznikol aj vd’aka prostriedkom projektu 7 FP PriSciNet.

Mgr. Monika Míkva - E-mail: monika.mlkva@gmail.com

Katedra chémie Pedagogickej fakulty Trnavskej univerzity

Priemyselná 4, 91843 Trnava, Slovenská republika

prof. PhDr. Lubomír Held, CSc. - E-mail: Iheld@truni.sk

Katedra chémie Pedagogickej fakulty Trnavskej univerzity

Priemyselná 4, 91843 Trnava, Slovenská republika 